\title{
"Islamic social reporting disclosure as a form of social responsibility of Islamic banks in Indonesia"
}

\begin{tabular}{|c|c|}
\hline \multirow{4}{*}{ AUTHORS } & Kuat Waluyo Jati (D) https://orcid.org/0000-0003-2174-7501 \\
\hline & Linda Agustina (D https://orcid.org/0000-0002-6596-2054 \\
\hline & Indah Muliasari (1) https://orcid.org/0000-0001-9770-4968 \\
\hline & Diah Armeliza (D https://orcid.org/0000-0001-5144-6393 \\
\hline ARTICLE INFO & $\begin{array}{l}\text { Kuat Waluyo Jati, Linda Agustina, Indah Muliasari and Diah Armeliza (2020). } \\
\text { Islamic social reporting disclosure as a form of social responsibility of Islamic } \\
\text { banks in Indonesia. Banks and Bank Systems, 15(2), 47-55. } \\
\text { doi:10.21511/bbs.15(2).2020.05 }\end{array}$ \\
\hline DOI & http://dx.doi.org/10.21511/bbs.15(2).2020.05 \\
\hline RELEASED ON & Monday, 27 April 2020 \\
\hline RECEIVED ON & Wednesday, 25 March 2020 \\
\hline \multirow[t]{2}{*}{ ACCEPTED ON } & Wednesday, 15 April 2020 \\
\hline & 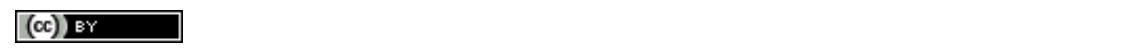 \\
\hline LICENSE & $\begin{array}{l}\text { This work is licensed under a Creative Commons Attribution } 4.0 \text { International } \\
\text { License }\end{array}$ \\
\hline JOURNAL & "Banks and Bank Systems" \\
\hline ISSN PRINT & $1816-7403$ \\
\hline ISSN ONLINE & $1991-7074$ \\
\hline PUBLISHER & LLC "Consulting Publishing Company "Business Perspectives" \\
\hline FOUNDER & LLC "Consulting Publishing Company "Business Perspectives" \\
\hline
\end{tabular}

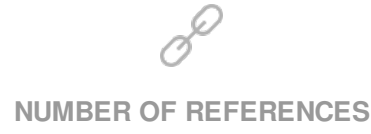

30

\section{NUMBER OF FIGURES}

0
$-=-$
$-=-$

NUMBER OF TABLES

3

(C) The author(s) 2021. This publication is an open access article. 


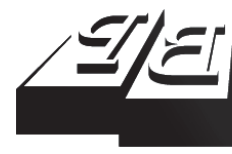

\section{BUSINESS PERSPECTIVES}

LLC "CPC "Business Perspectives" Hryhorii Skovoroda lane, 10, Sumy, 40022, Ukraine www.businessperspectives.org

Received on: $25^{\text {th }}$ of March, 2020 Accepted on: $15^{\text {th }}$ of April, 2020 Published on: $27^{\text {th }}$ of April, 2020

(C) Kuat Waluyo Jati, Linda Agustina, Indah Muliasari, Diah Armeliza, 2020

Kuat Waluyo Jati, M.Si., Lecturer, Faculty of Economics, Universitas Negeri Semarang, Indonesia. (Corresponding author)

Linda Agustina, M.Si., Lecturer, Faculty of Economics, Universitas Negeri Semarang, Indonesia.

Indah Muliasari, M.Ak., Lecturer Faculty of Economics, Universitas Negeri Jakarta, Indonesia.

Diah Armeliza, M.Ak., Lecturer, Faculty of Economics, Universitas Negeri Jakarta, Indonesia.
This is an Open Access article, distributed under the terms of the Creative Commons Attribution 4.0 International license, which permits unrestricted re-use, distribution, and reproduction in any medium, provided the original work is properly cited.

Conflict of interest statement: Author(s) reported no conflict of interest
Kuat Waluyo Jati (Indonesia), Linda Agustina (Indonesia),

Indah Muliasari (Indonesia), Diah Armeliza (Indonesia)

\section{ISLAMIC SOCIAL REPORTING DISCLOSURE AS A FORM OF SOCIAL RESPONSIBILITY OF ISLAMIC BANKS IN INDONESIA}

\begin{abstract}
Sharia-compliant companies had to add Islamic Social Reporting when disclosing Corporate Social Responsibility information due to its characteristics. Shariacompliant companies in Indonesia still do not do this much, and it is very interesting to study, because every sharia-based entity must comply with sharia provisions in all aspects of its activities, including when compiling social reporting. The purpose of this study is to analyze the influence of profitability, liquidity, leverage, and an Islamic Governance Score on Islamic Social Reporting in Islamic commercial banks in Indonesia. The sampling is carried out using a purposive sampling technique for up to 10 Islamic commercial banks with a six-year observation period, so there are 60 units of analysis. The data are collected using a documentation technique. The analysis in the study uses panel data regression. Based on a Random Effect Model, the study showed that profitability and leverage do not affect Islamic Social Reporting, while liquidity and the Islamic Governance Score had an impact on the Islamic Social Reporting.
\end{abstract}

Keywords

JEL Classification Islamic social reporting, Islamic governance score, profitability, liquidity, leverage

M14, M41

\section{INTRODUCTION}

The corporate sustainability depends not only on profits, but also on maintaining harmony with the social environment around it. Some efforts that lead to better local communities in all aspects are known as Corporate Social Responsibility (CSR). Act No. 40 of 2007 on Limited Liability Companies requires reporting on CSR in Indonesia. Companies also recognized and considered the importance of disclosing CSR information (Khoirudin, 2013). This also held true for Islamic commercial banks, although most were not been listed on the Indonesia Stock Exchange (IDX).

Indonesian Islamic banking statistics show that Islamic commercial banks in Indonesia are now in the growth stage. The growth of Islamic banks in Indonesia has led to the birth of an ethic of disclosing social responsibility. As an Islamic-based entity, an Islamic bank had to pay attention to the environment and surrounding communities as a form of its concern and responsibility. Unfortunately, CSR was not able to fully disclose information on social responsibility in general on the Islamic themes. Therefore, Islamic Social Reporting (ISR) must exist to complete the disclosure of social responsibility information that was contained in CSR. ISR, which is still voluntary, results in different reporting by each Islamic entity. 
Researchers have developed an Islamic Social Reporting (ISR) index, which measures the implementation of social responsibility by sharia banks (Othman, Thani, \& Ghani, 2009). This index is suitable for Islamic banking because it reveals various matters related to Islamic principles. There are six categories in the ISR index, namely investment and finance investment and finance, products and services, employees, the community, the environment and corporate governance. Each category is measured by items in accordance with sharia (Islamic) principles. However, the disclosure of ISR in Indonesian Islamic Commercial Banks in the last few years is still not full, even from the six categories available. There are seven items that were not disclosed at all (Rosiana, Arifin, \& Hamdani, 2015).

Studies related to sharia banking CSR began to develop in Indonesia, including Fitria and Hartanti (2010), who found that overall higher scores were obtained by conventional banking than sharia banking. For Islamic banking institutions, the results of scoring with the ISR index are lower than those of the Global Reporting Initiative (GRI) index. In addition, Othman and Thani (2010) explained that the level of ISR in the annual reports of companies that were sampled in the study was considered to be minimal. Therefore, it is important to carry out ISR-related research in Indonesia so that Islamic entities use appropriate indices to conduct social disclosure.

\section{LITERATURE REVIEW}

Haniffa (2002) states that ISR is an extension of social reporting on the role of companies in the economy and in a spiritual perspective to meet people's expectations. ISR's emphasis is on the social justice of reporting related to the environment, minority rights, and employees. In the Islamic context, a community has the right to know about organizational activities in order to see whether a company continues to operate according to Islamic laws and achieves the set goals (Baydoun \& Willett, 1998). ISR continues to be extensively developed by Othman, Thani, and Ghani (2009) and now uses six categories to measure it, namely: Funding and Investment; Products and Services; Employee; Community and Social Affairs; Environment; and corporate governance. Each category is measured by items in accordance with sharia principles.

This research was developed based on Sharia Enterprise Theory, Legitimacy Theory, and Stakeholder Theory. Sharia Enterprise Theory puts God at the center of all things as the return of man and the universe. Therefore, humans only act as His representatives (khalitullah fil ard). This causes humans to obey all God's laws. Human and natural obedience is intended to return to God with a calm soul, and this process involves unification of oneself with fellow humans and nature as well as with various inherent laws (Triyuwono, 2012).
Shariah Enterprise Theory is more appropriate for an economic system that bases itself on sharia (Islamic) values. The implication of this theory is everything in this world belongs to Allah and is only left for the humans and must be managed as well as possible. Owned assets must not be stockpiled or deposited, so that they can be rotated and productive and useful for others. Therefore, the use of assets should be through implementing social responsibility, because one of the obligations of Islamic banking is to care about people around it by providing social responsibility as best as possible.

Barkemeyer (2007) mentions that there are two things that become the strength of the use of legitimacy theory in explaining corporate social responsibility in developing countries. First, a clearer picture of a company's motivation to increase social responsibility is seen from the profit maximization motive. Second, organizational legitimacy can include cultural factors that shape different institutional pressures in different contexts. The description can be the basis that the theory of legitimacy can be used to explain CSR disclosure. Disclosure of corporate social responsibility is done to get positive value and legitimacy from the community.

Explanation of corporate governance mechanisms by disclosing corporate social responsibility can use the theory of legitimacy. The corporate gov- 
ernance mechanism gives the company confidence to disclose its corporate social responsibility. This means that with an adequate corporate governance mechanism, the company will still receive positive benefits that get legitimacy from the community, which ultimately affects the increase in its profits in the future.

Stakeholder theory explains the corporate CSR disclosure as a way to communicate with stakeholders. The implication is that the company will voluntarily implement CSR, because it is part of the company's role to the stakeholders. This theory, if applied well, will encourage the company to implement CSR in the best possible manner. Through the implementation of CSR, it is expected that the stakeholders' desires can be accommodated well to generate a harmonious relationship between the company and its stakeholders. A harmonious relationship will result in the achievement of sustainability by the company.

Given previous research, some factors influencing ISR include size, profitability, leverage, board composition and industry type, bank type, issuance of ownership certificate (sukuk), company age, proportion of independent commissioners, size of the board, size of the Islamic supervisory board, environmental performance, Islamic securities, and Islamic Governance Score (Othman, Thani, \& Ghani, 2009; Maulida, Yulianto, \& Asrori, 2014; Rosiana, Arifin, \& Hamdani, 2015; Lestari, 2016). Due to some differences in results of previous research, this study will reexamine the influence of profitability, liquidity, leverage and Islamic Governance Score on ISR disclosure.

\section{HYPOTHESES DEVELOPMENT}

This study uses return on assets (ROA) to measure profitability. This ratio is used, since out of several profitability ratios, ROA is most often highlighted in the analyses of financial statements. This is because ROA is considered capable of showing the success of a company in making a profit. ROA can predict future benefits, as seen from past benefits measured using ROA. Profitability is the ability to earn profits. The more profit the company earns, the higher the cost of disclos- ing social reports. So, the companies in profitable position will tend to disclose wider information in their annual reports. Othman, Thani, and Ghani (2009), Taufik, Widiyanti, and Rafiqoh (2015) reveal that profitability has a positive influence on ISR disclosure, while Rosiana, Arifin, and Hamdani (2015) state that profitability has no effect on ISR disclosure.

\section{H1: Profitability has an impact on Islamic Social Reporting.}

Liquidity is a condition that shows the company's ability to fund its operations and pay off shortterm debt. Companies in a good financial position are likely to disclose more information in ISR than those with lower liquidity. Strong financial companies will tend to provide broad information than those with weak financial conditions. Companies with good liquidity have good financial structure. So, if the public is aware of these conditions, the company will indirectly show the validity of its performance.

This study uses the Financing-to-Debt Ratio (FDR) to measure Islamic banking liquidity in Indonesia. The use of FDR is based on interesting things related to tradeoffs that arise when measuring the liquidity with FDR. When FDR reaches $100 \%$, on the one hand, it will be considered that the bank has good liquidity because it is able to channel its financing from third parties' funds collected. But at the same time, Islamic banks that reach $100 \%$ FDR will be named by the Bank of Indonesia (as the regulator of banking activities) as being under pressure because their shortterm funds have run out.

Liquidity is the company's ability to pay off its short-term obligations without having to liquidate its long-term assets. This study takes a view that if liquidity is seen in FDR, then when it is said that liquidity reaches or is close to $100 \%$, Islamic banks will not disclose their ISR. It is because they do not want stakeholders to know that they are under pressure to fulfill short-term funds. Companies with good liquidity will tend to disclose extensive information to show their credibility, but will reverse if FDR reaches $100 \%$. According to Kamil and Herusetya (2012) and Putra (2014), liquidity has no effect on ISR disclosure. 


\section{H2: Liquidity has an impact on the disclosure of Islamic Social Reporting.}

The leverage ratio shows the company's ability to meet the payment of all debts, both long-term and short-term debts. Companies that have high leverage have the obligation to meet their credit information needs. The higher the level of leverage, the more likely they will violate the credit agreement, so that they will try to report that current profits are higher. To report profits as high, managers must reduce some costs, including those on CSR activities. Kamil and Herusetya (2012) reveal that the leverage ratio has a negative effect on CSR disclosure.

Leverage is the ability of an entity to repay its debts. Meek, Roberts, and Gray (1995) argue that companies that have a high level of leverage have broad and open disclosures, so that the lenders can have higher trust in them. Companies with the high debt level tend to meet information needs of creditors. More information about the company's ability to pay its obligations is needed by shareholders and creditors. Kamil and Herusetya (2012) reveal that the leverage ratio has a negative effect on CSR disclosure. Rosiana, Arifin, and Hamdani (2015) and Taufik, Widiyanti, and Rafiqoh (2015) state that leverage does not significantly influence the disclosure of ISR.

\section{H3: Leverage has an impact on the disclosure of Islamic Social Reporting.}

Islamic Governance Score (IGS) is a proxy for the characteristics of the sharia supervisory board (SSB) as measured by the presence of sharia supervisory board members, the number of SSB, cross membership, educational background, and the experience or reputation (Farook \& Lanis, 2007). According to Wan Abdullah, Percy, and Stewart (2011), SSB can improve the CSR disclosure, because it can make good comparisons on several companies' reporting, so that it can find out which one is the best. The main functions of the sharia supervisory board are to direct, review and oversee the activities of Islamic banks and to ensure that they are running in accordance with Islamic laws. The authority possessed by the SSB is believed to be able to increase the disclosure of Islamic banking social responsibility. Farook and
Lanis (2007), Wan Abdullah, Percy, and Stewart (2011), and Haniffa and Cooke (2002) prove that Islamic governance scores have a positive effect on the disclosure of Islamic Social Reporting. Whereas Taufik, Widiyanti, and Rafiqoh (2015) and Rosiana, Arifin, and Hamdani (2015) state that the Islamic Governance Score cannot influence the Islamic Social Reporting index.

\section{H4: Islamic Governance Score has an impact on the disclosure of Islamic Social Reporting.}

\section{DATA AND METHODS}

This study aims to analyze the influence of profitability, liquidity, leverage, and Islamic governance scores on Islamic social reporting. The research was conducted among ten Islamic banks in Indonesia for the six-year observation period. The sampling was done using a purposive sampling technique to receive a representative sample in accordance with predetermined criteria. The criteria were as follows:

1) Islamic banks that issued annual reports for six consecutive years;

2) Annual reports could be available from each bank's website; and

3) The data required for the study were fully available.

The sample used in this study is 10 Islamic banks with 60 units of analysis.

This study used one dependent variable, the ISR, and four independent variables, namely profitability, liquidity, leverage and Islamic Governance Score (IGS). ISR disclosure was measured by Islamic Social Reporting index, based on Othman, Thani, and Ghani (2009), containing 44 items. Profitability was measured by Return on Assets (ROA), which was the result of net income sharing divided by total assets. Liquidity was measured using the Financing-to-Deposit Ratio (FDR), using the formula for the total share of financing provided by the banks at the expense of third parties. Leverage was measured using the Debt-to-Equity Ratio (DER), which was the quotient of total debt 
with total equity. Islamic Governance Score was measured by the presence of the sharia supervisory board members, the number of SSBs, cross membership, educational background and experience or reputation.

Data analysis techniques in this study were descriptive and inferential statistics using panel data regression. Regression was used to see the relationship between the disclosure of Islamic banking social reports in accordance with Islamic principles and the independent variables of profitability, liquidity, leverage and Islamic Governance Score. Before testing the hypothesis using the panel data regression analysis, testing was conducted to determine the estimation methods of testing, whether using a common effect, a fix effect, or a random effect.

\section{RESULTS}

Table 1 describes variables used in this study. All variables have an average value greater than the standard deviation, except for profitability. This shows that the data is well distributed.

Table 1. Variable description

Source: Processed data.

\begin{tabular}{l|c|c|c|c|c}
\hline \multicolumn{1}{c}{ Variable } & $\mathbf{N}$ & Min & Max & Mean & $\begin{array}{c}\text { Std. } \\
\text { deviation }\end{array}$ \\
\hline Liquidity & 60 & .46 & 1.68 & .9083 & .13874 \\
\hline $\begin{array}{l}\text { Leverage } \\
\text { Profitability }\end{array}$ & 60 & .06 & 12.24 & 2.7947 & 2.63441 \\
\hline $\begin{array}{l}\text { Islamic } \\
\text { governance }\end{array}$ & 60 & -1.74 & 3.20 & .8011 & .87407 \\
score & 60 & .50 & 1.00 & .9000 & .16723 \\
\hline $\begin{array}{l}\text { Islamic social } \\
\text { reporting }\end{array}$ & 60 & .21 & .74 & .4885 & .14296 \\
\hdashline $\begin{array}{l}\text { Valid } N \\
\text { (listwise) }\end{array}$ & 60 & - & - & - & - \\
\hline
\end{tabular}

This study uses panel regression testing with a random effect estimation method, since the test results using E-views lead the researchers to apply the estimation method. The results of hypothesis testing are shown in Table 2. They show that only Liquidity and Islamic Governance Score can influence Islamic Social Responsibility with the significance value of 0.0478 and 0.0001 , respectively, while the profitability and leverage have no effect. The independent variables in this model only have an effect of $18.93 \%$ ( $R^{2}$ of $\left.18.93 \%\right)$. Table 3 summarizes the acceptance or rejection of hypotheses.

Table 2. Hypotheses testing results

Source: Processed data by E-view.

\begin{tabular}{l|c:c:c:c}
\hline Variable & Coefficient & Std. error & t-statistic & Prob. \\
\hline C & 0.193701 & 0.142286 & 1.361351 & 0.1790 \\
\hdashline Profitability & -0.003024 & 0.016297 & -0.185547 & 0.8535 \\
\hdashline $\begin{array}{l}\text { Leverage } \\
\text { Liquidity }\end{array}$ & -0.004127 & 0.006264 & -0.658918 & 0.5127 \\
\hdashline $\begin{array}{l}\text { Islamic } \\
\text { governance }\end{array}$ & 0.208078 & 0.102797 & -2.024169 & 0.0478 \\
score & & & & \\
\hline
\end{tabular}

Table 3. Hypotheses acceptance or rejection

\begin{tabular}{|c|c|}
\hline Hypotheses & Conclusion \\
\hline $\begin{array}{l}\text { H1: Profitability has an impact on Islamic social } \\
\text { reporting }\end{array}$ & Rejected \\
\hline $\begin{array}{l}\text { H2: Liquidity has an impact on the disclosure of } \\
\text { Islamic social reporting }\end{array}$ & Accepted \\
\hline $\begin{array}{l}\text { H3: Leverage has an impact on the disclosure of } \\
\text { Islamic social reporting }\end{array}$ & Rejected \\
\hline $\begin{array}{l}\text { H4: Islamic Governance Score has an impact on } \\
\text { the disclosure of Islamic social reporting }\end{array}$ & Accepted \\
\hline
\end{tabular}

\section{DISCUSSION}

Profitability has no influence on the disclosure of Islamic Social Reporting (ISR). This explains that high or low level of profitability cannot determine the extent of disclosure of ISR by the Islamic commercial banks in Indonesia. The companies that earn high profits may not necessarily have high social activities and social reporting, and with high profits, these companies will focus on maximum achievement of profits, so that reporting of social activities does not get too much attention, as do those which have lower profits. Not all low-profit companies can pay for social reporting or vice versa, and as a solution of low profits, the companies will create a good corporate image through improved social reporting.

Haniffa (2002) states that in the Islamic perspective, a company must be willing to provide full disclosure without seeing whether it will provide benefits or not. Therefore, when profitability is either high or low, it will still disclose its ISR. According to the Sharia Enterprise Theory (SET), 
Allah is the center of everything, He is the Highest stakeholder, and everything that exists is trustworthy, so it must be managed seriously. By paying attention to this theory, the companies with high or low profitability will always well manage His mandates, demonstrating a high degree of ISR disclosure.

According to Stakeholder Theory, companies must be responsible to their stakeholders; one form of their responsibilities is ISR reporting, so even though they have low profitability, they will always report ISR because it is part of their accountability. The Legitimacy Theory explains that in order to survive well, the companies must receive legitimacy from the community, always observing applicable customs and norms.

One form of the companies' compliance with the norm is social activity towards the community, which they report as a form of their accountability. Thus, they will always disclose their social activities to receive legitimacy from the community, not paying attention to the level of profitability. The results of this study are in line with Hossain and Hammami (2009), Wahyuni (2018) and Rosiana, Arifin, and Hamdani (2015), who stated that profitability has no effect on Islamic Social Reporting (ISR).

Liquidity influences the disclosure of Islamic Social Reporting (ISR). Liquidity is the company's ability to finance its operational activities and shortterm debt. Those that have good liquidity, will certainly disclose more social activities. However, in this study, liquidity, as measured by FDR, shows a negative effect, meaning that when the liquidity of an Islamic bank is high, it is unlikely to make an ISR disclosure. Indriani (2013) explains that companies will disclose more detailed information if their liquidity conditions are weak. This is because with weak liquidity conditions, managers want to inform stakeholders that the company's condition is still position. In other words, the information disclosure made is used to show the other positive side that has been achieved by the company.

In this study, liquidity has a negative effect on ISR due to the sample data showing that the average Islamic banking liquidity in Indonesia during the observation year was 0.901 , which means liquidity ratio close to $100 \%$. Referring to SE No. 9/24/DPbS on the assessment of the soundness of commercial banks based on sharia (Islamic) principles, it can be seen that there are five composite ratings. Low rating means that Islamic banks and business units are classified as good and able to overcome the negative effects of economic conditions and financial industries. On average, during the year of observation, Islamic banking in Indonesia is in composite three, which is $85 \%$ (lower than $100 \%$ ). This condition shows that Islamic banking has some weaknesses, which cause its composite rating to deteriorate if it does not immediately take corrective actions. So, it was clear that this condition put the Islamic banking in a depressed position, because it approached $100 \%$ of its liquidity ratio and was classified as composite three.

Islamic banks are institutions that collect and distribute funds from and to the public and get capital investors, so that they are trusted to maintain public funds and investments (Hassan \& Harahap, 2010). As a result of extremely high liquidity that exceeds the Bank Indonesia's requirements, the banks' management have decided not to disclose ISR if it is based on its liquidity ratio. Therefore, in addition to being transparent in management, Islamic banks must also be transparent in terms of morals, that is they must report the management of these funds on ISR. However, in terms of the FDR, it applies a contradictive condition, where higher liquidity will reduce the ISR disclosure to maintain the stakeholders' legitimacy to Islamic banks. This study is in line with Affandi and Nursita (2019); other studies related to the effect of liquidity on ISR are those by Purwani, (2018), Kamil and Herusetya (2012) and Putra (2014), which showed that liquidity had no effect on the disclosure of Islamic Social Reporting (ISR).

Leverage does not influence the disclosure of Islamic Social Reporting (ISR). This shows that high and low leverage of a company does not affect the disclosure of its ISR. Lestari (2016) states that disclosing ISR does not affect debt repayment. Companies with high leverage strongly depend on creditors, and the creditors usually want the company (debtor) to be open in its management process, including social activities undertaken by the debtor. In addition, Williams and Zinkin (2010) state that Islam requires the companies to be transparent in conducting their business activities. 
Therefore, the companies will be more flexible in reporting their social activities. This can be explained by the stakeholder theory, where the creditor is one of the stakeholders, so the company must take responsibility for them, and the disclosure of ISR is one form of accountability to the creditor. Conversely, those with a low level of leverage will always report on their social activities so that their image in the community acquires legitimacy. In addition, stakeholders are very concerned about the company's activities, which can harm banks and unfair trades and apply Islamic values in every aspect of life, so Islamic banks should be able to ensure accountability to their ISR without taking into account corporate leverage (Di Bella \& Al-Fayoumi, 2016).

Legitimacy theory explains that in order for companies to survive, they need legitimacy from the community. Through the disclosure of ISR, a company will create a good understanding of the community that it cares about them so that the legitimacy can be obtained and the continuity of the company is maintained. These results are in line with the those of Kasih and Rini, (2018), Rosiana, Arifin, and Hamdani (2015), and Lucyanda and Siagian (2012), which showed that leverage does not affect the disclosure of Islamic Social Reporting (ISR).

Islamic Governance Score influences the disclosure of Islamic Social Reporting (ISR). The Islamic Governance Score, which is proxied by the characteristics of the sharia board, determines the disclosure of ISR by the company. That is, as the function of the sharia supervisory board is to ensure that the company runs in accordance with Islamic principles, the reports produced by the sharia board provide certainty to the share- holders and corporate clients that the company has fulfilled the ethical expectations they want (Aribi \& Gao, 2011).

Farook, Kabir Hassan, and Lanis (2011) noted that in Qur'an and the Sunnah of the Prophet Muham, there are several verses that prescribe charity to create a just and responsible social economic life, including zakat, waqf, and alms. Since Islam requires the implementation of those concepts, the Sharia Supervisory Board will ensure that the company implements this concept in the form of social activities. Williams and Zinkin (2010) state that Islam requires all companies to be transparent in conducting business activities. When the company has done the charity, it will report it in its ISR. Thus the tighter the supervision/role of the sharia supervisory board, the higher the disclosure of the ISR. This can be explained by the theory of sharia enterprises theory (SET) that Allah is the center of everything, Allah is the Highest stakeholder, and everything that exists deserves trust, so it must be managed seriously.

In Islam, one form of mandates is that rights of others are in someone else's property. One of the mandates is the existence of the company and its assets, performance and profits, so out of these three things, there are other people's rights that need to be shared and channeled in social activities. Thus, the higher the supervision of the sharia supervisory board that is proxied by the Islamic Governance Score, the higher the disclosure of Islamic Social Reporting by the company. The results of this study are in line with Haniffa and Cooke (2002), Farook and Lanis (2007) and Wan Abdullah, Percy, and Stewart (2011), who state that Islamic Governance Score has an impact on the disclosure of Islamic Social Reporting (ISR).

\section{CONCLUSION}

This study illustrates that profitability and leverage do not affect ISR. In Islamic principles, social values have a sufficient share to ensure that relations between creatures work as they should. The company makes a profit or not, has a large or small debt, the company naturally presents its social report.

Liquidity and IGS influence ISR. It is clear that when an entity has good liquidity, it means that it has sufficient ability to carry out social reporting when such reporting requires costs. While the effect of IGS on ISR means that the sharia supervisory boards at sharia banks in Indonesia have been properly fulfilling their duties to ensure that sharia principles are respected. 
This study was conducted on Islamic banking in Indonesia, which could lead to differences in results for other business sectors. Future studies may use facilities other than Islamic banks, such as companies that conduct sharia business and are listed in the Indonesia Sharia Stock Index.

\section{AUTHOR CONTRIBUTIONS}

Conceptualization: Kuat Waluyo Jati, Linda Agustina.

Data curation: Linda Agustina, Indah Muliasari.

Formal analysis: Kuat Waluyo Jati, Diah Armeliza.

Investigation: Linda Agustina, Indah Muliasari, Diah Armeliza.

Methodology: Linda Agustina, Diah Armeliza.

Project administration: Kuat Waluyo Jati, Indah Muliasari.

Supervision: Linda Agustina, Indah Muliasari.

Validation: Kuat Waluyo Jati, Diah Armeliza.

Visualization: Kuat Waluyo Jati, Indah Muliasari.

Writing - original draft: Kuat Waluyo Jati, Linda Agustina.

Writing - reviewing \& editing: Kuat Waluyo Jati, Linda Agustina, Indah Muliasari, Diah Armeliza.

\section{REFERENCES}

1. Affandi, H., \& Nursita, M. (2019). Profitabilitas, Likuiditas, Leverage, dan Ukuran Perusahaan: Sebuah Analisis Islamic Social Reporting (Isr) Pada Perusahaan yang Terdaftar di Jii. Majalah Ilmiah Bijak, 16(1), 1-11. http://dx.doi. org/10.31334/bijak.v16i1.318

2. Aribi, Z. A., \& Gao, S. S. (2011). Narrative disclosure of corporate social responsibility in Islamic financial institutions. Managerial Auditing Journal, 27(2), 199-222. http://dx.doi. org/10.1108/02686901211189862

3. Barkemeyer, R. (2007). Legitimacy as a key driver and determinant of CSR in developing countries (Paper for the 2007 Marie Curie Summer School on Earth System Governance) (23 p.). University of St Andrews and Sustainable Development Research Centre (SDRC) School of Management. Retrieved from http://citeseerx.ist. psu.edu/viewdoc/download?doi $=10 \cdot 1 \cdot 1 \cdot 509.8633 \& \mathrm{rep}=\mathrm{rep} 1 \&$ typ $\mathrm{e}=\mathrm{pdf}$

4. Baydoun, N., \& Willett, R. J. (1998). Islam and accounting: Ethical issues in the presentation of financial information. Accounting, Commerce \& Finance: The Islamic Perspective, 12(1), 1-25. Retrieved from http://ecite.utas. edu.au/100534
5. Di Bella, V., \& Al-Fayoumi, N. (2016). Perception of stakeholders on corporate social responsibility of Islamic Banks in Jordan. EuroMed Journal of Business, 11(1), 30-56. https://doi.org/10.1108/ EMJB-01-2015-0003

6. Farook, S., \& Lanis, R. (2007). Banking on Islam? Determinants of corporate social responsibility disclosure. Proceedings of 6th International Conference on Islamic Economics and Finance (pp. 217-247). Retrieved from https://pdfs.semanticscholar.org/ c121/3bee1308195c5b1ad2617d37 81a794ae0381.pdf

7. Farook, S., Kabir Hassan, M., \& Lanis, R. (2011). Determinants of corporate social responsibility disclosure: The case of Islamic banks. Journal of Islamic Accounting and Business Research, 2(2), 114-141. https://doi. org/10.1108/17590811111170539

8. Fitria, S., \& Hartanti, D. (2010). Islam dan Tanggung Jawab Sosial: Studi Perbandingan Pengungkapan Berdasarkan Global Reporting Initiative Indeks dan Islamic Social Reporting Indeks. Simposium Nasional Akuntansi XIII. Purwokerto. Retrieved from https://www. academia.edu/10555825/ ISLAM_DAN_TANGGUNG
JAWAB_SOSIAL_STUDI_PERBANDINGAN_PENGUNGKA PAN_BERDASARKAN_GLOBAL_REPORTING_INITIATIVE_ INDEKS_DAN_ISLAMIC_SOCIAL_REPORTING_INDEKS

9. Haniffa, R. (2002). Social reporting disclosure: An Islamic perspective. Indonesian Management \& Accounting Research, 1(2), 128-146. Retrieved from https:// ru.scribd.com/doc/312550684/ Haniffa-R-Social-ReportingDisclosure-An-Islamic-Perspective-2002

10. Haniffa, R. M., \& Cooke, T. E. (2002). Culture, corporate governance and disclosure in Malaysian corporations. Abacus, 38(3), 317-349. Retrieved from https:// papers.ssrn.com/sol3/papers. cfm?abstract id $=336822$

11. Hassan, A., \& Harahap, S. S. (2010). Exploring corporate social responsibility disclosure: the case of Islamic banks. International Journal of Islamic and Middle Eastern Finance and Management, 3(3), 203-227. Retrieved from https:// ideas.repec.org/a/eme/imefpp/ v3y2010i3p203-227.html

12. Hossain, M., \& Hammami, H. (2009). Voluntary disclosure in the annual reports of an emerging country: The case of Qatar. 
Advances in Accounting, 25(2), 255-265. https://doi.org/10.1016/j. adiac. 2009.08.002

13. Indriani, E. W. (2013). Faktorfaktor yang mempengaruhi luas pengungkapan sukarela dan implikasinya terhadap asimetri informasi. Accounting Analysis Journal, 2(2), 208-217. Retrieved from https://journal.unnes. ac.id/sju/index.php/aaj/article/ view/1578

14. Kamil, A., \& Herusetya, A. (2012) Pengaruh Karakteristik Perusahaan Terhadap Luas Pengungkapan Kegiatan Corporate Social Responsibility. Media Riset Akuntansi, 2(1), 1-17. Retrieved from http:// jurnal.bakrie.ac.id/index.php/ journal_MRA/article/view/43

15. Kasih, A. M., \& Rini (2018). Factors Influencing Islamic Social Reporting Disclosure in Some Selected Countries (Conference Paper). KnE Social Sciences, 276296. Retrieved from https://pdfs. semanticscholar.org/7a00/8b4d 7e4d2ea45a491e3569e81fcb1a8d ac04.pdf

16. Khoirudin, A. (2013). Corporate governance dan pengungkapan Islamic Social Reporting pada perbankan syariah di Indonesia. Accounting Analysis Journal, 2(2), 227-232. Retrieved from https:// journal.unnes.ac.id/sju/index.php/ aaj/article/view/2919/2700

17. Lestari, S. (2016). Pengaruh Tingkat Profiabilias, Likuiditas, Leverage, Ukuran Perusahaan Dan Umur Perusahaan Terhadap Pengungkapan Islamic Social Reporting Pada Perbankan Syariah Indonesia Tahun 2010-2014. Jurnal Akuntansi UNESA, 4(2), 1-24. Retrieved from https://jurnalmahasiswa.unesa.ac.id/index. php/jurnal-akuntansi/article/ view/14722/12778

18. Lucyanda, J., \& Siagian, L. G. (2012). The influence of company characteristics toward corporate social responsibility disclosure. Proceedings of the 2012 International Conference on Business and Management. Phuket, Thailand. Retrieved from http://portal.kopertis3.or.id/ bitstream/123456789/1931/1/
\%5BSem-02\%5D\%20027CSRJuricaL\%26LadyGPS-The_Influence_of_Company.pdf

19. Maulida, A. P., Yulianto, A., \& Asrori. (2014). Analisis FaktorFaktor yang Mempengaruhi Pengungkapan Islamic Social Reporting (ISR). Makalah Simposium Nasional Akuntansi 17. Lombok. Universitas Mataram.

20. Meek, G. K., Roberts, C. B., \& Gray, S. J. (1995). Factors influencing voluntary annual report disclosures by US, UK and continental European multinational corporations. Journal of International Business Studies, 26(3), 555572. Retrieved from https://www. jstor.org/stable/155561

21. Othman, R., \& Thani, A. M. (2010). Islamic social reporting of listed companies in Malaysia. International Business \& Economics Research Journal (IBER), 9(4), 135-144. https://doi.org/10.19030/ iber.v9i4.561

22. Othman, R., Thani, A. M., \& Ghani, E. K. (2009). Determinants of Islamic social reporting among top Shariah-approved companies in Bursa Malaysia. Research Journal of International Studies, 12(10), 4-20. Retrieved from http://lela. stiemj.ac.id/wp-content/uploads/ Islamic-social-reporting-Kel6.pdf

23. Purwani, T., Nurlaela, \& Wijayanti, S. A. (2018). The Influence of Company Size, Profitability, Liquidity, Leverage and Tax Avoidance Disclosure Against the Islamic Social Reporting on Companies Listed On the Indonesian Stock Index of Sharia. Proceeding ICTESS (International Conference on Technology, Education and Social Sciences). Retrieved from http://ejurnal.unisri.ac.id/ index.php/proictss/article/ view/2194/1956

24. Putra, H. F. (2014). Analisis Pelaksanaan dan Pengungkapan Corporate Social Responsibility (CSR) pada Perbankan Syariah di Indonesia Berdasarkan Indeks Islamic Social Reporting (ISR). Jurnal Ilmiah Mahasiswa FEB, 3(1). Retrieved from https://jimfeb. ub.ac.id/index.php/jimfeb/article/ view/1704
25. Rosiana, R., Arifin, B., \& Hamdani, M. (2015). Pengaruh Ukuran Perusahaan, Profitabilitas, Leverage, dan Islamic Governance Score Terhadap Pengungkapan Islamic Social Reporting (Studi Empiris pada Bank Umum Syariah di Indonesia Tahun 2010-2012). Jurnal Bisnis Dan Manajemen, 5(1), 87-104. https://doi.org/10.15408/ ess.v5i1.2334

26. Taufik, T., Widiyanti, M., \& Rafiqoh, R. (2015). Pengaruh Islamic Governance Score, Leverage Dan Profitabilitas Terhadap Islamic Social Reporting Indexpada Bank Umum Syariah Di Indonesia. Jurnal Manajemen Dan Bisnis Sriwijaya, 13(2), 177198. Retrieved from https://www. neliti.com/publications/283868/ pengaruh-islamic-governancescore-leverage-dan-profitabilitasterhadap-islamic-s

27. Triyuwono, I. (2012). Akuntansi Syariah: Perspektif, Metodologi, dan Teori ( $2^{\text {nd }}$ ed.). Jakarta: Rajawali Press.

28. Wahyuni, S. (2018). Islamic Social Reporting Disclosure and Determinant Factors: Empirical Evidence from Islamic Banks in Indonesia. Advances in Social Science, Education and HumanitiesResearch, 231, 389-392. https://download.atlantis-press. com/article/25901788.pdf

29. Wan Abdullah, W. A., Percy, M. \& Stewart, J. (2011). Corporate social responsibility in Islamic banks: A study of Shariah Supervisory Board disclosures and zakat disclosures in Malaysian and Indonesian Islamic banks. AFAANZ Conference (pp. 3-5).

30. Williams, G., \& Zinkin, J. (2010). Islam and CSR: A study of the compatibility between the tenets of Islam and the UN Global Compact. Journal of Business Ethics, 91(4), 519-533. https://doi. org/10.1007/s10551-009-0097-x 